\title{
Analysis of Variance in Food Preference For Enhanced Captive Rearing of Crocodilus nilotica
}

\author{
John A Ogbodo ${ }^{1 *}$, Mike T Iwar ${ }^{2}$ and Mohammed Adeyemi ${ }^{1}$ \\ ${ }^{1}$ Department of Forestry and Wildlife, Nnamdi Azikiwe University, Awka, Nigeria \\ ${ }^{2}$ Department of Wildlife and Range Management, Federal University of Agriculture \\ Makurdi, Nigeria \\ *Corresponding Author: John A Ogbodo, Department of Forestry and Wildlife, \\ Nnamdi Azikiwe University, Awka, Nigeria.
}

Received: July 14, 2021

Published: September 15, 2021

(C) All rights are reserved by John A Ogbodo., et al.

\begin{abstract}
The overall objective of this paper is to determine the alternative food preference of Nile crocodiles towards enhancing their captive rearing for increased populations. The feeding behaviour of four Nile crocodiles (Crocodylus nilotica) comprising of three juveniles (six-month old, each) and one adult (26-month-old) was observed for a period of eight weeks in captivity. Each of the four experimental animals was randomly placed into four separate treatment (plastic) tanks, labelled as: E1, E2, E3 and E4, respectively. The crocodiles were fed with four animal proteins: (a) poultry offal; (b) lizard meat; (c) toad meat; and (d) mixture of diet: a, b, and c. Feeding was done twice per week: morning - the first day; and evening - the second day. The amounts of diets introduced and consumed during treatments were weighed every two hours of experimentation in grammes. Diet and consumption time analyses were performed (in mean \pm standard deviation) and the outcomes were further subjected to a one-way Analysis of Variance (ANOVA) statistics. The results show that the diets supplied were consumed at the average total rates of $589.20 \mathrm{~g} \pm 8.29$ (lizard meat), $574.50 \mathrm{~g} \pm 16.90$ (toad meat) and $434.20 \pm 17.17$ (poultry offal). There were no significant difference between the treatment effects and the consumption time. This study concludes that poultry intestines are strange to the Nile crocodiles. The study recommends that poultry offal should be used as food supplements for captive rearing of Nile crocodiles for improved productivity and sustainable livelihoods..
\end{abstract}

Keywords: Alternative Diet; Crocodilus nilotica; Captive Rearing; Consumption Time; Feeding Treatment.

\section{Background Information}

Crocodilus nilotica commonly known as Nile crocodiles, are present in a variety of freshwater wetlands including lakes, rivers, swamps and brackish [1] but they also exhibit semi-aquatic lifestyles as matured females lay eggs in holes on land. Crocodilus nilotica have adaptive features for a carnivorous life: huge skull with powerful jaws. The Nile crocodile is a carnivorous predator. It preys on small fish, frogs, insects, and small aquatic invertebrates (e.g. worms). According to Caldwell [2], Nile crocodile also preys on waterfowl, king fisher through snatching. Nile crocodile also consumes dead animals that would otherwise pollute the waters [3]. International Union for Conservation of Nature (IUCN) refers to Nile crocodiles as 'corner stone species' because they through their activities, maintain ecosystem structures and functions: 
their selective predation on fish species recycles nutrients and maintains wet refugia $[2,4,5]$. Therefore, Nile crocodiles play an extremely important role in stabilizing the ecological food chain. Nile crocodile is a top predator in the environment, which is responsible for keeping in check the population of species such as the catfish. Despite the importance of Nile crocodiles to the environment, the reptiles are severely threatened by water pollution, habitat destruction and indiscriminate poaching in many countries of the World.

The increasing and indiscriminate killing of Nile crocodile (Crocodilus niloticus) by humans is one of the major challenges in the conservation and sustainability of this species. This scenario has resulted in dwindling the population of this aquatic wildlife species thereby risk being extinct from the surface of the Earth. This issue is of global concern to conservationists and national governments. As such, Nile crocodile is listed on Convention for International Trade on Endangered Species [5]. In Nigeria, this species is number 47 in Schedule I of Decree No. 11 of 1985 (Now cap 108, 1990) Endangered species (ES) Laws of the Federation of Nigeria [6]. Both the CITES and the Nigerian ES laws prohibit the indiscriminate killing of the reptile for international trade. Despite the availability of the above mentioned regulations among others, there are increasing over-exploitations of Nile crocodiles in the country and most poachers illegally trade their products with neighboring countries such as Cameroun, Chad and Niger $[2,7]$. Therefore, captive rearing of Nile crocodile could reverse the dwindling population problem of the animal in the country. Hence, there is a need to rear and manage them in captivity, thus, the aim of this present study is to determine the alternative food preference of Crocodilus niloticus other than fish towards providing cheaper variety of diets using poultry offals, lizard meat and toad meat for the effective management of Nile crocodiles in captivity. Furthermore, the result of this study will be used as a reference material by crocodilian farmers, policy makers, wildlife managers for advancing the sustainable utilization of Nile crocodiles for both present and future human generations.

\section{Description of study site}

This experiment was conducted in the Department of Forestry, Wildlife and Range Management, University of Agriculture, Makurdi (UAM) in Benue State, Nigeria. Using the World geodetic System
84 (WGS84) Projection, Makurdi (Capital City of Benue State) is situated on latitude $7^{\circ} 43^{\prime} 50^{\prime \prime} \mathrm{N}$ and longitude $8^{\circ} 32^{\prime} 10^{\prime \prime} \mathrm{E}$ [8]. Makurdi is basically a low-lying and gently undulating terrain. The terrain ranges from steep slopes through deep valleys to hilly relief [9]. Makurdi has high drainage density many seasonal streams and River Benue. River Benue is the major water body passing through Makurdi. River Benue is fed by the following tributaries that are found within Benue State: River Katsina Ala, River Mkomon, River Amile, River Duru, River Loko, River Konshisha, River Kpa, River Okpokwu, River Mu, River Be, River Aya, River Apa Ogede, River Ombi; and River Doma in Nassarawa State.

Figure 1 shows the study area and the water bodies found within Makurdi. According to OnlineNigeria [9], Makurdi has a tropical sub-humid climate with two distinct seasons: wet and dry seasons. The wet season starts from April to October, covering a period of seven months. The annual rainfall total ranges between 1,200 mm and 1,500 $\mathrm{mm}$. Temperatures are generally very high during the day, particularly in the months of March and April. Along the river valleys, high temperatures combine with relative high humidity to produce severe weather conditions. Makurdi records average daily temperatures of $35^{\circ} \mathrm{C}$ (maximum) and $21^{\circ} \mathrm{C}$ (minimum) during the dry (hot) season and $37^{\circ} \mathrm{C}$ (maximum) and $16^{\circ} \mathrm{C}$ (minimum) in the Harmattan season [10].

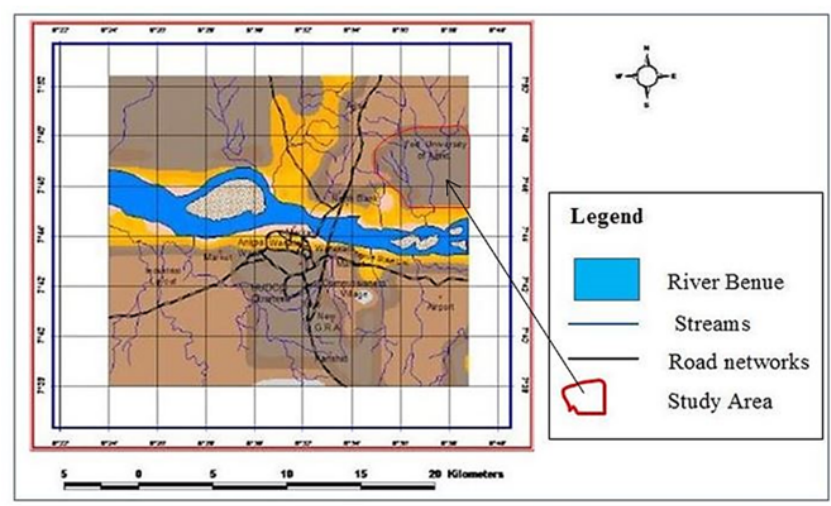

Figure 1: Map of Makurdi showing study area (modified from Abah, 2013). 


\section{Methodology}

This study was carried out between $1^{\text {st }}$ July and $31^{\text {st }}$ August 2005 , covering a period of eight weeks. Thus, experimental period falls within the raining season in the study area of Makurdi. Three juveniles (six - month old, each) and one sub-adult (26 - month old) Nile crocodiles were used for this experiment. They were obtained from River Doma, a tributary of River Benue located in Nasarawa State of Nigeria. The three juveniles had average body weight of 44 $\pm 2.55 \mathrm{~g}$ ( $23.50 \pm 1.45 \mathrm{~cm}$ long) each; and the sub-adult ( $34 \mathrm{~cm} \mathrm{long}$ ) weighed 108g [11]. Four plastic tanks measuring $1.50 \mathrm{~m}^{*} 2.50 \mathrm{~m}$ were arranged using in a completely randomized design; and they were respectively labelled as treatment enclosures E1, E2, E3 and E4. The Nile crocodiles were randomly placed in the four treatment enclosures. The treatment tanks were each slanted at $45^{\circ}$ to enable the individual Nile crocodiles balance their bodies against the treatment enclosures $[12,13]$. Every treatment enclosure had a volume of $3 \mathrm{~m}^{3}$. Meanwhile, a 2 - cubic meter volume of freshwater (from a stream situated at the South Core of the University of Agriculture Makurdi) was used in filling the treatment enclosures throughout the period of this experiment. The cleaning of the treatment enclosures was done twice a week to tally with the Feeding Treatment Days (FTDs). To realize the objectives of this study, the following measurements were taken.

\section{Measurement of crocodilian body temperature}

Every time the treatment enclosures were refilled, the water temperature (in degrees Celsius) was taken using a laboratory thermometer. This was necessary to determine the moderate temperature which could enable the Nile crocodiles to feed properly, adequately move about and keep their balance in the water $[13,14]$.

\section{Diet consumption analysis}

Three animal protein diets, namely: (a) poultry intestines, i.e. offal of Gallus domesticus, (b) lizard meat, i.e. carcass of Agama agama, and (c) toad meat, i.e. carcass of Bufo regularis and (d) a mixture of: $a, b$, and c diet sources; were administered to the experimental reptiles. The poultry offals were collected from noninfectious chickens butchered at the Central abattoir located at Wurukum Market in Makurdi Local Government Area of Benue State. Live toads and lizards were captured within the campus of University of Agriculture Makurdi. These three food materials were weekly collected from the field in the evening that preceded the Feeding Treatment Days (FTDs). The food materials were further minced using a kitchen knife and stored in a freezer for use during FTDs, i.e. the First Feeding Treatment Day (FTD - 1) and Second Feeding Treatment Day (FTD - 2). Feeding Treatments was carried out two times in a week: FTD - 1 (morning) and FTD - 2 (evening). The feeding was done between $10 \mathrm{AM}$ and mid-day. $12.50 \mathrm{~g}$ wet weight of the minced diets of a: poultry offal, b: lizard meat and c: toad meat was each measured [15] using a digital beam balance under a controlled situation. For controlled weighing, windows were closed and fans, turned off. $3.0 \mathrm{~g}$ was measured out of each of the food sources: $\mathrm{a}, \mathrm{b}$ and $\mathrm{c}$ and mixed together to form a balance diet: labelled as (d). On FTD - 1 (Week: 1), diets: a, b and c were introduced into the three treatment enclosures (plastic tanks) of E1, E2 and E3 respectively. The fourth treatment enclosure (E4) which was housing the sub-adult Nile crocodile was given the balanced diet - d. This feeding approach was repeated for weeks: 3, 5 and 7 in FTD - 1. Whereas, feeding treatment using the same diets was variedly experimented on the Nile crocodiles in FTD - 2 (Weeks: 2, 4, 6 and 8). The daily quantity of each of three animal protein diets (poultry offal, lizard meat, toad meat and balanced mixture of: a, b, and c sources) were determined, tank by tank (in E1 - E4) per FTD (morning and evening respectively); while the weekly diet consumed per treatment enclosure was further determined at the end of FTD (evenings). The amounts of diets introduced and consumed by the crocodiles were weighed and recorded.

\section{Analysis of time of feeding by the Nile crocodiles}

Likewise, the introduction time of diet was determined. The amounts of diet consumed by the Nile crocodiles per treatment enclosure were observed and determined every two hours of experimentation.

\section{Statistical analyses: Diet and time treatments}

The statistical analyses of Diet consumed, and the time of consumption were performed in mean \pm standard deviation. Also, a one-way Analysis of Variance (ANOVA) statistics was applied to the resulting outcomes based on a completely randomized experimental design in determining (a) the response of Nile crocodiles to preferred food diet (in grammes) and (b) time (minutes) in line with Grenard, (1991). Hence, the model equation: Yij $=\mathrm{N}+\mathrm{tj}+$ Eij was applied to table 1 and 4 and the results were 
further tested at confidence limits of 0.005 (for diet treatment effects) and 0.005 and 0.001 (for difference in feeding time).

Key to above model equation:

- $\quad$ Yij $=$ Individual Observations of $\mathrm{j}^{\text {th }}$ treatment in the $\mathrm{i}^{\text {th }}$ plot

- $\quad \mathrm{N}=$ General population mean of all possible similar experiments

- $\quad t j=$ Effects of the $j^{\text {th }}$ experiment

- $\quad$ Eij $=$ Experimental Error containing all uncontrolled sources of variation.

\section{Results and Discussion}

Measurement of crocodilian body temperature

The average body temperature of the Nile crocodiles used in this experiment was determined to be $25.50^{\circ} \mathrm{C}$. Temperature measurement was taken because Nile crocodiles usually do not properly feed at either high or very low body temperatures (Karen, 2004). Furthermore, Pooley (1971, in: Karen, 2004) expressed that Nile crocodiles cease to feed at low body temperatures and become torpid. Karen (2004) study confirmed this condition, when the crocodiles she experimented with had no interest in feeding at a low temperature of $15.6^{\circ} \mathrm{C}$. Earlier, Pooley and Gans (1976) indicate that crocodiles are unable to maintain their balance and move properly in water when temperature drops to $7.20^{\circ} \mathrm{C}$. When crocodiles experience such a situation, they are liable to drown. Naturally, crocodiles correct this climatic factor by warm basking in the sun (Karen, 2004).

\section{Diet consumption analysis}

The daily quantity of each of three animal protein diets (poultry offal, lizard meat, toad meat and balanced mixture of: $a, b$, and c sources) were determined, tank by tank (in E1-E4) during FTDs (1 and 2). In figure $2,117.50 \mathrm{~g}$ of poultry offals, $144.50 \mathrm{~g}$ of toad meat and $134.40 \mathrm{~g}$ were consumed in treatment enclosure (E1); whereas, figure 3 shows the weekly and total amounts of diet consumed in E2 - E4 during the study period.

In figure 4 , a total of $1,590 \mathrm{~g} \pm 35.65$ of the controlled diet $(\mathrm{a}+\mathrm{b}$ $+c$ ) and individual diet sources of $1,606 \mathrm{~g} \pm 40.10$ were consumed by the Nile crocodiles during the experiment.

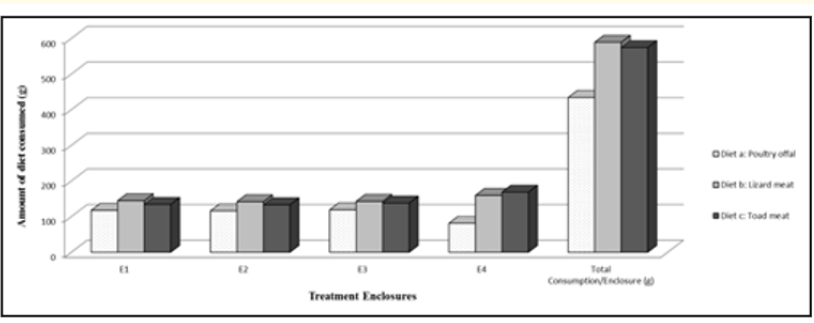

Figure 2: Total individual diets consumed (in grammes) per Nile crocodile in captivity.

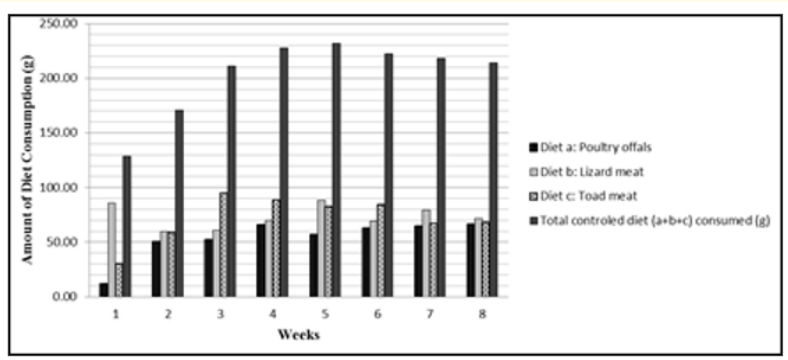

Figure 3: Total controlled diet consumed (in grammes) per week.

Analysis of time of feeding by the Nile crocodiles

The feeding behaviours of the crocodile were observed two hours after administering diets into the treatment enclosure and the outcome is presented in figure 5. During the research period, the Nile crocodiles spend much time to eat the poultry offal $(1,565$ minutes), meaning about 26 hours. While the crocodiles took 601 minutes (i.e. 10 hours) to consume the lizard meat and 701 minutes (approximately 12 hours) to feed on the toad meat.

Diet and time treatments

Table 1 shows that F-calculated (F-cal.) at $\mathrm{P}>0.005$ is less than F-tabulated (F-stat.), i.e., 5.4227 (F-cal.) < 6.3500 (F-stat.). This outcome indicates that, no significant difference exists among 


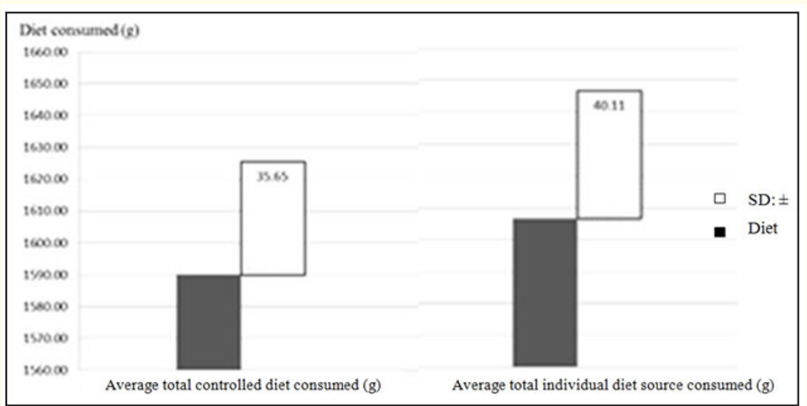

Figure 4: Comparison of average total diet consumption rates (in grammes) by the Nile crocodiles.

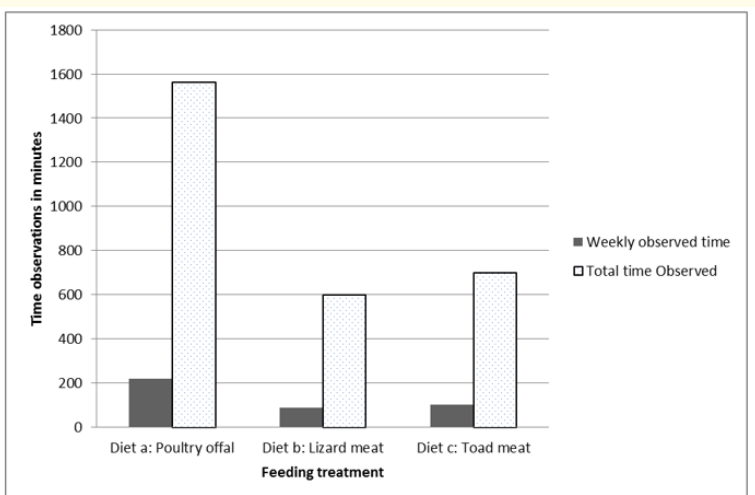

Figure 5: Comparison of weekly and total time observations for diet consumption (in minutes).

\begin{tabular}{|l|c|c|c|c|c|c|c|}
\hline Variable & $\begin{array}{c}\text { d.f (degree of } \\
\text { freedom }\end{array}$ & $\begin{array}{c}\text { Sum of square } \\
\text { (SS) }\end{array}$ & $\begin{array}{c}\text { Mean sum } \\
\text { of square } \\
\text { (MSS) }\end{array}$ & F-cal. & $\begin{array}{c}\text { F-stat. } \\
\mathbf{( 2 , 3 3 )}\end{array}$ & $\begin{array}{c}\text { Confidence } \\
\text { interval }\end{array}$ & Interpretation \\
\hline Diet treatment & 2 & 48096.4738 & 24048.2369 & 5.4227 & 6.3500 & 0.005 & $\begin{array}{c}\text { No significant } \\
\text { difference }\end{array}$ \\
\hline Errors & 33 & 146345.2592 & 4434.7048 & & & & \\
\hline Total & 35 & 194441.7330 & & & & & \\
\hline
\end{tabular}

Table 1: ANOVA to determine relationship among the diet sources as preferred by the Nile crocodiles.

the diet sources used in this study to feed the Nile crocodiles in captivity. In conclusion, this result has shown that irrespective of the variation that among the diet sources of poultry offal, lizard meat and toad meat, the Nile crocodiles could still derive healthy and productive benefits from these alternative food sources.
From table 2, we can deduce that, there is no significant difference in the time of consumption as exhibited by the Nile crocodiles in captivity at the degree of freedom of $F(2,171)$ and probability levels: 0.005 and 0.001 ; F-tabulated $(3.07,4.49)>$ F-calculated (0.0519).

\begin{tabular}{|c|c|c|c|c|c|c|c|}
\hline Variable & $\begin{array}{l}\text { d.f (degree } \\
\text { of freedom }\end{array}$ & $\begin{array}{c}\text { Sum of square } \\
\text { (SS) }\end{array}$ & $\begin{array}{l}\text { Mean sum of } \\
\text { square (MSS) }\end{array}$ & F-cal. & $\begin{array}{c}\text { F-stat. } \\
(2,171)\end{array}$ & $\begin{array}{c}\text { Confidence } \\
\text { interval }\end{array}$ & Interpretation \\
\hline $\begin{array}{l}\text { Diet } \\
\text { treatment }\end{array}$ & 2 & 252.4436 & 126.2218 & 0.0519 & $\begin{array}{l}3.07 \\
4.49\end{array}$ & $\begin{array}{l}0.005 \\
0.001\end{array}$ & $\begin{array}{c}\text { No significant } \\
\text { difference }\end{array}$ \\
\hline Errors & 171 & 416048.5081 & 2433.0322 & & & & \\
\hline Total & 173 & 416300.9517 & & & & & \\
\hline
\end{tabular}

Table 2: ANOVA in determining relationship in the preferred time of feeding by the Nile crocodiles. 
The outcome of this study has shown that the crocodiles are not familiar with poultry intestines. The poultry offal was strange to Nile crocodiles possibly because the intestine were internal parts of an animal; hence, crocodiles do not always see the offal in their ecosystem. Therefore, lizard meat and toad meat can be served separately as a diet for Nile crocodiles during captive rearing either in university or private farms; but poultry offal (intestines) must be served the animals as food supplement together with other food sources, for example: as used in this study or with fish, worms, buffalo meat, etc. Such a prescribed food ration will enhance captive rearing of Nile crocodile. Adequate feeding of Nile crocodile in captive farming will ensure their healthy growth and increase population (FAO, 1989). Furthermore, this study shows that a crocodile consumed at least twenty-nine (29) grammes of the food sources per day; and this conforms to feeding standard guideline for Nile Crocodiles in captive management by the Food and Agriculture Organization (FAO) of the United Nations (Table 3).

\begin{tabular}{|l|c|}
\hline Crocodile body length $\mathbf{( c m )}$ & $\begin{array}{c}\text { Required amount of food } \\
\text { (g) by crocodile }\end{array}$ \\
\hline$<35-50$ & $15-30$ \\
\hline $50-75$ & $30-50$ \\
\hline $76-100$ & $50-75$ \\
\hline $101-125$ & $75-150$ \\
\hline $126-150$ & $150-250$ \\
\hline $151-200$ & $250-500$ \\
\hline$>201$ & 500 and above \\
\hline
\end{tabular}

Table 3: Daily food requirement for crocodilian growth (FAO, 1989).

Karen (2004), FAO (1989) and de Vos (1981) expressed that, when using a variety of crocodilian foods such as: fresh fish, buffalo, worms and meat of large rodents, there will be no significant difference in the feeding treatment and time effects at a probability level of 0.005 . This present study also supports the findings of the authors mentioned above. In line with Karen (2004), we have also confirmed that food is eaten both during daytime and at night by Nile crocodiles.

\section{Conclusion and Recommendations}

This research has demonstrated that poultry offal can be served together with lizard and toad meats to Nile crocodiles in captivity. In terms of food preference, lizard meat $(589.20 \mathrm{~g} \pm 8.288)$ is most preferred, followed by toad meat $(574.50 \mathrm{~g} \pm 16.903)$ and least preferred is poultry offal $(434.20 \pm 17.168)$. Both the one-way ANOVA and F-test statistics at confidence levels (0.005 and 0.001) show no significant differences among the diet treatment effects and in the time of feeding by the Nile crocodiles in captivity; demonstrating that the animal proteins experimented in this study have the potential to be used in university or commercial farms for advancing future research and improving social livelihoods.

Consequently, the following four (4) recommendations are made as a way forward for captive management of Nile crocodiles by both smallholder and commercial farmers:

- $\quad$ Poultry offal should not be solely served to the Nile crocodiles in captivity; otherwise, they might become malnourished and become less reproductive.

- At favourable conditions, diet leftovers (i.e., un-eaten food materials) should indicate that crocodiles had taken to their satisfaction. Hence, crocodilian farmers should ration diets by varying the amounts of food served the crocodiles to ensure that there is always left-over after feeding time.

- Crocodiles in captivity should be free from disturbance to avoid stress. Stress (e.g., temperature heed) makes crocodiles not to feed but it is only by feeding that they can grow to maturity faster than their counterparts in the wild.

- In a completely intensive captive rearing of Nile crocodiles, food materials, as those used in this research, should be eviscerated before freezing to prevent poisoning with the animal's body toxins.

\section{Competing Interest Declaration}

The authors declare that they have no competing interests.

\section{Acknowledgement}

Special thanks go to the reviewers and editors for their valuable comments that improved this published article. 


\section{Bibliography}

1. Grenard S. "Handbook of alligators and crocodiles". Krieger Publishing co. Malabar, Flridda (1991): 107-150.

2. Caldwell John. "World trade in crocodilian skins 2006 - 2008". United Nations Environment Programme World Conservation Monitoring Center (UNEP-WCMC). Cambridge (2010): 35.

3. Robbins CT. "Wildlife feeding and nutrition (2nd ed.)". Academic press Inc. London (1992): 30.

4. Britton A. "Distribution of Crocodylus niloticus". African Journal of Wildlife (2012).

5. IUCN. Nile crocodile (1996).

6. LFN. Decree No 11 of 1985 (Now cap 108, 1990) Laws of the Federation of Nigeria Endangered species". In: Legal framework for animal rights and game management in Nigeria (1990).

7. Cott HB and Pooley AC. "Crocodiles - the status of crocodiles in Africa”. 2 (1972): 104.

8. Abah Roland Clement. "An application of geographic information system in mapping flood risk zones in a north central city in Nigeria". African Journal of Environmental Science and Technology 7.6(2013): 365-371.

9. OnlineNigeria. Makurdi, Benue State (2015).

10. DistanceFrom.com. Latitude and longitude of Makurdi, Benue State (2015).

11. FAO - Food and Agricultural Organization. "The management of crocodiles in captivity". FAO conservation guide. Rome 22 (1989): 1-43.

12. Mopurgo B., et al. "Food preference and fish atractibility of young Nile crocodiles". In: $10^{\text {th }}$ Proceeding of the Crocodilian Society. Gainsville. International Union of Conservation of Nature (IUCN) 2 (1990): 70-80.

13. Karen Higginbottom. "Wildlife tourism: impacts, management and planning". Common Ground Publishing Pty Ltd. Altona Vic 3018. Australia (2004): 301.
14. Awake. "Can you smile at crocodile? Report on St. Augustine's Alligator farm and zoological garden". India (2005): 11-13.

15. Pooley AC and Gans C. "Nile crocodile". American Crocodilian Society 4 (1976): 234-144.

Volume 5 Issue 10 October 2021

(C) All rights are reserved by John A Ogbodo., et al. 